\title{
"Kriminalisasi atas Partisipasi Masyarakat: Menyisir Kemungkinan terjadinya SLAPP terhadap Aktivis Lingkungan Hidup Sumatera Selatan"
}

\author{
Raynaldo Sembiring 1
}

\section{A. Pendahuluan}

Pada tanggal 31 Januari 2013 dalam sebuah Rapat Dengar Pendapat Umum (RDPU) mengenai ratifikasi Konvensi Rotterdam, seorang anggota Komisi VII ${ }^{2}$ meminta kepada pimpinan sidang untuk segera menghubungi Kapolri dikarenakan ditangkapnya 3 (tiga) orang aktivis lingkungan di Sumatera Selatan. Reaksi spontan dari anggota dewan tersebut menyiratkan pertanyaan tentang apa yang terjadi di Sumatera Selatan beberapa hari sebelumnya.

Tanggal 29 Januari 2013, terjadi tindakan represif dari aparat kepolisian dengan melakukan penangkapan terhadap 3 (tiga) orang aktivis lingkungan yang sedang menyampaikan pendapatnya dengan berunjuk rasa di depan Markas Kepolisian Daerah (Mapolda) Sumatera Selatan. Penangkapan yang dilakukan oleh aparat kepolisian mendapat kecaman dari berbagai pihak di Indonesia. Dikemudian hari ketiga aktivis lingkungan tersebut dikenal sebagai Anwar Sadat (Direktur Eksekutif Walhi Sumsel), Dedek Chaniago (Staf Walhi Sumsel), dan Kamaludin (Petani).

Anwar Sadat, dkk melakukan unjuk rasa di depan Mapolda Sumatera Selatan untuk membela hak petani dan masyarakat di Kabupaten Ogan Komering Ilir (OKI) terkait dengan konflik sengketa agraria dengan PTPN VII Unit Cinta Manis, dimana terjadi kekerasan oleh aparat kepolisian polres OKI di wilayah yang disengketakan. Unjuk rasa kemudian mendapat perlawanan dari anggota kepolisian yang sedang mengamankan aksi unjuk rasa tersebut. Penyebabnya adalah pagar Mapolda yang roboh, yang menurut keterangan beberapa saksi ${ }^{3}$

\footnotetext{
${ }^{1}$ Saat ini bertanggungjawab sebagai Kepala Divisi Advokasi Kasus dan ADR ICEL

2 Anggota Komisi VII tersebut adalah Ir. Nazaruddin Kiemas dari Fraksi PDI Perjuangan.

${ }^{3}$ Dalam pembuktian di persidangan saksi-saksi yang dihadirkan dari aparat kepolisian yaitu Kamarudin bin H.Gustam, Abdul Gabi bin Choli, Karsono bin Hadi, Ujang Tabrani bin Umar Pai, Indra Gunawan bin Ibrahim menyatakan robohnya pagar Mapolda Sumsel diawali dengan orasi dari Anwar Sadat dan Dede Chaniago yang kemudian diikuti dengan dorongan terhadap pagar Mapolda Sumsel.
} 
dari aparat kepolisian dilakukan oleh masyarakat yang sedang berunjuk rasa. Atas robohnya pagar tersebut, aparat kepolisian kemudian melakukan penangkapan terhadap beberapa pengunjuk rasa yang diantaranya adalah Anwar Sadat, Dedek Chaniago, dan Kamaludin. Foto Anwar Sadat yang berlumuran darah pada saat ditangkap oleh aparat kepolisian menimbulkan respon dari berbagai pihak. Pendampingan yang dilakukan oleh Anwar Sadat, Dedek Chaniago, dan aktivis Walhi Sumsel lainnya kepada masyarakat di Kabupaten OKI mendapat balasan berupa penangkapan dan kekerasan terhadap Anwar Sadat dkk.

Dalam proses persidangan, perkara atas nama Anwar Sadat dan Dedek Chaniago digabungkan. Tulisan ini akan mencoba memberikan analisis terkait penangkapan terhadap Anwar Sadat dan Dedek Chaniago yang dalam hal ini merupakan aktivis lingkungan yang hak-haknya dilindungi oleh Pasal 66 Undang-Undang Nomor 32 Tahun 2009 tentang Perlindungan dan Pengelolaan Lingkungan Hidup (UUPPLH).

\section{B. Partisipasi masyarakat yang dilindungi dalam UUPPLH}

Banyak teori dan pendapat mengenai bentuk-bentuk partisipasi masyarakat. A.M. Hendropriyono menyebutkan dalam sosial kontrol, aksi unjuk rasa dan demonstrasi merupakan partisipasi politik masyarakat yang dapat berfungsi sebagai pressure kepada pemerintah untuk lebih mentolerir aspirasi mereka. ${ }^{4}$ Dalam hal ini partisipasi masyarakat merupakan bagian yang tidak terpisahkan dalam proses demokrasi. Edmund Burke dalam Reflections on the Revolution in France sebagaimana dikutip oleh A.M. Hendropriyono menyebutkan bahwa jika demokrasi diartikan sebagai sebuah kebebasan, maka kebebasan yang dimaksud yaitu sebuah kebebasan yang tidak mengganggu kebebasan orang lain. ${ }^{5}$

Jika mengacu kepada beberapa pendapat di atas, aktivitas menyampaikan pendapat yang dilakukan oleh Anwar Sadat dan Dedek Chaniago merupakan bagian dari partisipasi masyarakat. Dalam isu lingkungan hidup, hak

4 A.M. Hendropriyono, "Fenomena Demokrasi di Indonesia", diunduh dari www.hendropriyono.com/2013/12/fenomena-demokrasi-di-indonesia/, pada tanggal 5 Januari 2014.

${ }^{5}$ Edmune Burke, "Reflections on the Revolution in France" (London: J.M. Dent and Sons, Ltd, 1910), hal. 25 
berpartisipasi diamanatkan dalam Prinsip 10 Deklarasi Rio sebagaimana disebutkan: 6

"Environmental issues are best handled with participation of all concerned citizens, at the relevant level. At the national level, each individual shall have appropriate access to information concerning the environment that is held by public authorities, including information on hazardous materials and activities in their communities, and the opportunity to participate in decision-making processes. States shall facilitate and encourage public awareness and participation by making information widely available. Effective access to judicial and administrative proceedings, including redress and remedy, shall be provided."

Partipasi masyarakat telah dikenal sejak Undang-Undang Nomor 4 Tahun 1982 tentang Ketentuan-ketentuan Pokok Pengelolaan Lingkungan Hidup (UULH), sebagaimana disebutkan dalam Pasal 6 ayat (1): ${ }^{7}$

"Setiap orang mempunyai hak dan kewajiban untuk berperan serta dalam rangka pengelolaan lingkungan hidup"

Mengenai fungsi peran serta di bidang lingkungan hidup, Koesnadi Hardjasoemantri mengemukakan: ${ }^{2}$

"Peran serta masyarakat dalam pengelolaan lingkungan hidup mempunyai jangkauan luas. Peran serta tersebut tidak hanya meliputi peran serta para individu yang terkena berbagai peraturan atau keputusan administratif, akan tetapi meliputi pula peran serta kelompok dan organisasi dalam masyarakat. Peran serta efektif dapat melampaui kemampuan orang seorang, baik dari sudut kemampuan keuangan maupun dari sudut kemampuan pengetahuannya, sehingga peran serta kelompok dan organisasi

\footnotetext{
6 Principle 10 of the Rio Declaration on Environment and Development, http://www.unep.org/Documents.Multilingual/Default.asp?DocumentID=78\&ArticleID=11 63, diunduh pada 10 Desember 2013.

7 Pasal 6 ayat (1), Undang-Undang Nomor 4 Tahun 1982 tentang Ketentuan-ketentuan Pokok Pengelolaan Lingkungan Hidup

8 Koesnadi Hardjasoemantri, "Aspek Hukum Peran Serta Masyarakat dalam Pengelolaan Lingkungan Hidup", Pidato Pengukuhan, Universitas Gajah Mada, 1985, hal. 2, sebagaimana dikutip oleh Siti Sundari Rangkuti, "Hukum Lingkungan dan Kebijaksanaan Lingkungan Nasional", Airlangga University Press, 2005, hal. 283
} 
sangat diperlukan, terutama yang bergerak di bidang lingkungan hidup."

Dalam perkembangannya, UUPPLH juga secara tegas menyebutkan bahwa perlindungan dan pengelolaan lingkungan hidup salah satunya dilaksanakan berdasarkan asas partisipatif ${ }^{9}$ yang berarti setiap anggota masyarakat didorong untuk berperan aktif dalam proses pengambilan keputusan dan pelaksanaan perlindungan dan pengelolaan lingkungan hidup, baik secara langsung maupun tidak langsung. ${ }^{10}$ Bahkan dalam penjelasan UUPPLH bagian umum disebutkan: ${ }^{11}$

"Perbedaan mendasar antara Undang-Undang Nomor 23 Tahun
1997 tentang Pengelolaan Lingkungan Hidup dengan Undang-
Undang ini adalah adanya penguatan yang terdapat dalam
Undang-Undang ini tentang prinsip-prinsip perlindungan dan
pengelolaan lingkungan hidup yang didasarkan pada tata kelola
pemerintahan yang baik karena dalam setiap proses perumusan
dan penerapan instrumen pencegahan pencemaran dan/atau
kerusakan lingkungan hidup serta penanggulangan dan
penegakan hukum mewajibkan pengintegrasian aspek
transparansi, partisipasi, akuntabilitas, dan keadilan."

Menurut UUPPLH, dalam asas tata kelola pemerintahan yang baik, perlindungan dan pengelolaan lingkungan hidup salah satunya dijiwai oleh prinsip partisipasi. ${ }^{12}$

Partisipasi merupakan salah satu pilar tata kelola pemerintahan yang baik (good governance). Partisipasi berarti memberikan kesempatan pada semua pemangku kepentingan untuk ikut serta dalam setiap tahapan perencanaan, pengambilan keputusan, pelaksanaan, hingga evaluasi suatu kebijakan. ${ }^{13}$ Akses partisipasi masyarakat dalam pengambilan keputusan, utamanya dalam pengelolaan

\footnotetext{
9 Pasal 2 huruf (k), Undang-Undang Nomor 32 Tahun 2009 tentang Perlindungan dan Pengelolaan Lingkungan Hidup

10 Penjelasan Pasal 2 huruf (k), Undang-Undang Nomor 32 Tahun 2009 tentang Perlindungan dan Pengelolaan Lingkungan Hidup

11 Penjelasan bagian Umum angka (7) Undang-Undang Nomor 32 Tahun 2009 tentang Perlindungan dan Pengelolaan Lingkungan Hidup

12 Penjelasan Pasal 2 huruf (m), Undang-Undang Nomor 32 Tahun 2009 tentang Perlindungan dan Pengelolaan Lingkungan Hidup

${ }^{13}$ Indonesian Center for Environmental Law (ICEL), Menutup Akses, Menuai Bencana, (Jakarta: ICEL, 2008)
} 
lingkungan dan sumber daya alam, akan mendorong lahirnya produk kebijakan yang tidak hanya mementingkan pertumbuhan ekonomi tetapi juga menjaga kelestarian lingkungan dan hak-hak dasar masyarakat, melalui minimalisasi biaya sosial, ekonomi, dan lingkungan hidup. ${ }^{14}$ Akses partisipasi dalam pengambilan keputusan (access to participation in decision making) merupakan pilar demokrasi yang menekankan pada jaminan hak untuk berpartisipasi dalam proses pengambilan keputusan. Partisipasi dalam pengambilan keputusan ini dibagi dalam 3 bagian, yaitu: ${ }^{15}$

(1) Berpartisipasi dalam pengambilan keputusan dalam penetapan kebijakan dan program pembangunan;

(2) Berpartisipasi dalam proses pembentukan peraturan perundang-undangan; dan

(3) Berpartisipasi dalam pengambilan keputusan pada suatu kegiatan tertentu sesuai dengan kepentingannya.

Berdasarkan teori, pendapat dan peraturan perundang-undangan di atas, dapat dipastikan bahwa unjuk rasa yang dilakukan oleh Anwar Sadat dan Dedek Chaniago dalam pendampingan terhadap masyarakat merupakan bentuk partisipasi yang dilindungi dalam UUPPLH.

\section{Teori Strategic Lawsuit Against Public Participation (SLAPP)}

SLAPP merupakan terminologi baru yang dikenal di Indonesia sejak UUPPLH disahkan. Terminologi SLAPP dikenal melalui ketentuan Pasal 66 yang berbunyi:

$$
\begin{aligned}
& \text { "Setiap orang yang memperjuangkan hak atas lingkungan } \\
& \text { hidup yang baik dan sehat tidak dapat dituntut secara pidana } \\
& \text { maupun digugat secara perdata." }
\end{aligned}
$$

Jika membaca ketentuan Pasal 66, maka akan tersirat seperti hak imunitas bagi masyarakat dan aktivis lingkungan yang memperjuangkan hak atas lingkungan hidup yang baik dan sehat untuk terlepas dari tuntutan pidana maupun

\footnotetext{
${ }^{14} \mathrm{Ibid}$

15 Indonesian Center for Environmental Law (ICEL), Membuka Ruang, Menjembatani Kesenjangan, (Jakarta: ICEL, 2006)
} 
gugatan perdata. Ketentuan pasal ini memberikan perlindungan atas upayaupaya kriminalisasi yang terjadi dalam kasus lingkungan hidup.

Secara konseptual, ketentuan Pasal 66 didasarkan dari ketentuan Pasal 65 ayat (1) yang menyebutkan:

"Setiap orang berhak atas lingkungan hidup yang baik dan sehat sebagai bagian dari hak asasi manusia."

Heinhard Steiger, et.al. ${ }^{16}$ sebagaimana dikutip oleh Koesnadi Hardjasoemantri menyebutnya sebagai hak-hak subyektif (subjective rights), yaitu bentuk yang paling luas dari perlindungan seseorang. Koesnadi Hardjasoemantri kemudian menyebutkan bahwa hak tersebut memberikan kepada yang mempunyainya suatu tuntutan yang sah guna meminta kepentingannya akan suatu lingkungan hidup yang baik dan sehat itu dihormati, suatu tuntutan yang dapat didukung oleh prosedur hukum, dengan perlindungan hukum oleh pengadilan dan perangkat-perangkat lainnya. ${ }^{17}$ Tuntutan tersebut mempunyai dua fungsi, yaitu yang dikaitkan pada hak membela diri terhadap gangguan dari luar yang menimbulkan kerugian pada lingkungannya dan yang dikaitkan pada hak menuntut dilakukannya sesuatu tindakan agar lingkungannya dapat dilestarikan, dipulihkan, atau diperbaiki. ${ }^{18}$

Sebagaimana terminologinya, SLAPP pada dasarnya bertujuan untuk membungkam/mendiamkan partisipasi masyarakat. ${ }^{19}$ Penelope Canan dan George W. Pring, sebagaimana dikutip oleh Dwight H. Merriam dan Jeffrey A. Benson menyebutkan bahwa SLAPP merupakan tindakan dengan menggunakan mekanisme pengadilan untuk menghilangkan partisipasi publik dengan mendiamkan, mengganggu, dan menghalangi lawan politik. ${ }^{20}$ Tindakan SLAPP terhadap aktivis lingkungan pernah terjadi terhadap

\footnotetext{
${ }^{16}$ Heinhard Steiger, et.al. "The Fundamental Right to a Decent Environment" dalam "Trends in Enviromental Policy and Law", IUCN, Gland, Switzerland, 1980, sebagaimana dikutip oleh Koesnadi Hardjasoemantri dalam, "Hukum Tata Lingkungan", (Yogyakarta: Gajah Mada University Press, 2005), hal.102

17 Koesnadi Hardjasoemantri, "Hukum Tata Lingkungan", (Yogyakarta: Gajah Mada University Press, 2005), hal.102

18 Ibid

${ }^{19}$ Fiona Dobson, “Legal Intimidation" (1 ${ }^{\text {st }}$ edition, 2000) New York, sebagaimana dikutip oleh Josi Khatarina dalam "Slapp Suit In Indonesia: How It Takes Its Forms And How To Beat It", hal. 2

${ }^{20}$ Istilah ini diciptakan oleh Profesor Penelope Canan dan George W. Pring, sebagaimana dikutip oleh Dwight $\mathrm{H}$. Merriam dan Jeffrey A. Benson dalam tulisan Identifying and Beating a Strategic Lawsuit Against Public Participation
} 
Greenpeace di Britania Raya pada tahun 1997. ${ }^{21}$ Akibat dari tindakan SLAPP tersebut, Greenpeace kemudian tidak dapat melanjutkan advokasinya.

Saat ini belum ada pengertian yang baku mengenai SLAPP, sehingga akan lebih mudah mengenali SLAPP melalui 4 kriteria yang disampaikan oleh George W. Pring, yaitu:22

(1) Adanya keluhan, pengaduan, tuntutan dari masyarakat atas dampak kerusakan yang terjadi;

(2) Dilakukan terhadap masyarakat secara kolektif, individual, dan organisasi non pemerintah;

(3) Adanya komunikasi yang dilakukan kepada pemerintah atau pejabat yang berwenang;

(4) Dilakukan terhadap isu yang menyangkut kepentingan umum atau perhatian publik.

Kriteria kelima yang dapat ditambahkan bahwa SLAPP dilakukan dengan tidak berdasar dan mengandung motif politik atau motif ekonomi tersembunyi.23 Kriteria tersebut tentunya dapat terus berkembang mengikuti kondisi yang terjadi. Dari kriteria yang disampaikan oleh George W. Pring dapat dilihat bahwa pada umumnya yang menjadi "korban" dari tindakan SLAPP adalah masyarakat. George W. Pring dan Penelope Canan kemudian menegaskan bahwa pihak yang menjadi target SLAPP selain masyarakat biasanya adalah organisasi non pemerintah, jurnalis dan media. ${ }^{24}$ Pada perkembangan beberapa kasus SLAPP, pemidanaan atau gugatan yang dilakukan lebih bersifat intimidatif dan mengancam untuk menimbulkan ketakutan bagi masyarakat yang menjadi korban. Hal seperti ini menjadi salah satu contoh tindakan yang dapat menghilangkan/ membungkam partipasi publik.

\footnotetext{
${ }^{21}$ Fiona Dobson, “Legal Intimidation” (1 ${ }^{\text {st }}$ edition, 2000) New York, sebagaimana dikutip oleh Josi Khatarina dalam "SLAPP Suit In Indonesia: How It Takes Its Forms And How To Beat It", hal. 2

${ }^{22}$ George W Pring and Penelope Canan, SLAPPs: Getting Sued for Speaking Out (1 ${ }^{\text {st }}$ edition, 1996)

${ }^{23}$ Dwight H. Merriam and Jeffrey A. Benson, Identifying and Beating a Strategic Lawsuit Againts Public Participation

${ }^{24}$ George W. Pring and Penelope Canan, SLAPPs: Getting Sued for Speaking Out (1 ${ }^{\text {st }}$ edition, 1996)
} 
Ada beberapa tipe pelanggaran hukum yang terjadi dalam kasus SLAPP seperti:25 fitnah, gangguan yang mempengaruhi aktivitas sehari-hari, gangguan yang dilakukan terhadap pribadi (privat), konspirasi, tindakan yang berbahaya, tindakan yang menimbulkan kerugian. Fitnah merupakan tipe yang paling umum terjadi pada kasus SLAPP. ${ }^{26}$ Namun, pelanggaran hukum dengan tipetipe lainnya juga semakin umum terjadi. Kasus SLAPP sangat dimungkinkan banyak terjadi pada kasus terkait dengan lingkungan hidup. Ada beberapa kasus yang menjadi milestone dari perumusan Pasal 66 UUPPLH, antara lain kasus yang dialami oleh Dr. Rignolda Djamaludin. Dr. Rignolda adalah seorang ahli lingkungan yang berfokus pada isu lingkungan laut yang dimintakan kesaksian sesuai keahliannya dalam kasus pencemaran Teluk Buyat yang diduga dilakukan oleh PT Newmont Minahasa Raya (PT. NMR). Selain bersaksi di pengadilan, Dr. Rignolda juga menyampaikan pendapatnya kepada media sesuai dengan keahlian dan keberpihakannya sebagai aktivis lingkungan. Dalam kesaksiannya, Dr. Rignolda menyatakan bahwa memang terjadi pencemaran di Teluk Buyat yang menyebabkan penyakit Minamata yang diidap oleh masyarakat yang tinggal sekitar Teluk Buyat. Kesaksian dan pernyataan Dr. Rignolda yang akhirnya membuat PT NMR menggugat Dr. Rignolda dengan gugatan pencemaran nama baik. ${ }^{27}$

Contoh kasus yang dialami oleh Dr. Rignolda merupakan salah satu bentuk SLAPP. Dr. Rignolda dalam kapasitas sebagai masyarakat, ahli, dan aktivis lingkungan menyampaikan pendapatnya yang kemudian "dibalas" dengan gugatan oleh PT. NMR. Dalam kasus ini Dr. Rignolda telah melakukan partisipasinya secara layak. Menurut penulis, kelayakan partispasi yang dilakukan oleh Dr. Rignolda adalah dengan menyampaikan pendapatnya pada Harian Kompas tanggal 20 Juli 2004 dan Sinar Harapan tanggal 21 Juli 2004, yaitu mengenai operasi penambangan yang dilakukan PT. Newmont Minahasa Raya (PT. NMR). ${ }^{28}$ Pernyataan yang disampaikan melalui media massa merupakan bagian dari sebuah proses demokrasi. Selain itu perjuangan Dr.

${ }^{25}$ James A. Wells, "Exporting SLAPPS: International Use of the US SLAPP," To Suppress Dissent and Critical Speech, Temple International Comparative Law Journal, 1998

${ }^{26}$ Josi Khatarina, SLAPP Suit In Indonesia: How It Takes Its Forms And How To Beat It, Melbourne Law Masters, 2008

27 pernyataan yang groups.yahoo.com/neo/groups/kmnu2000/conversations/topics/15707?var=0, bersifat "Urgent Action" dari ELSAM bernomor: 08/PH/XI/ELSAM/04, solidaritas terhadap Dr. Rignolda Djamaludin (Oda), aktivis, Direktur Kelola, Manado, diunduh pada 5 Januari 2014

${ }^{28}$ Ibid 
Rignolda dalam membela hak-hak masyarakat korban pencemaran merupakan tindakan untuk mendapatkan lingkungan hidup yang baik dan sehat.

Ketentuan Pasal 66 hadir sebagai respon dari kasus-kasus seperti yang terjadi pada Dr. Rignolda. Secara terminologi, ketentuan Pasal 66 disebut sebagai Anti-SLAPP dikarenakan memberi perlindungan bagi masyarakat untuk memperjuangkan hak atas lingkungan hidup yang baik dan sehat. Namun ketentuan Anti-SLAPP dalam UUPPLH masih menimbulkan permasalahan pada penjelasan Pasal 66, sebagaimana disebutkan:

“Ketentuan ini dimaksudkan untuk melindungi korban dan/atau pelapor yang menempuh cara hukum akibat pencemaran dan/atau perusakan lingkungan hidup;

Perlindungan ini dimaksudkan untuk mencegah tindakan pembalasan dari terlapor melalui pemidanaan dan/atau gugatan perdata dengan tetap memperhatikan kemandirian peradilan."

Penjelasan Pasal 66 ini dapat menimbulkan multitafsir sehingga dapat mengecilkan arti dari partisipasi publik. "Tindakan pembalasan" pada penjelasan Pasal 66 sebaiknya jangan dibaca bahwa Pasal 66 hanya berlaku jika korban dan/atau pelapor sudah menempuh cara hukum, melainkan harus dibaca bahwa tindakan SLAPP dapat terjadi kapan saja, baik sebelum atau sesudah korban dan/atau pelapor menempuh cara hukum. ${ }^{29}$

\section{Menyisir kemungkinan terjadinya SLAPP terhadap Anwar Sadat dan Dedek Chaniago}

Dalam proses persidangan terlihat perdebatan pendapat yang signifikan mengenai robohnya pagar Mapolda Sumsel. Perbedaan pendapat ini yang menjadi fakta penting apakah partisipasi yang dilakukan telah layak atau tidak. Perbedaan pendapat diantara kedua pihak, yaitu pihak kepolisian dan pihak masyarakat (pengunjuk rasa) banyak sekali terdapat perbedaan. Jika saksi dari pihak kepolisian seluruhnya menyebutkan bahwa robohnya pagar adalah akibat dari aksi unjuk rasa dan menyebut Anwar Sadat dan Dedek Chaniago

29 Raynaldo Sembiring, Strategic Lawsuit Againts Public Participation: Pengantar, http://www.icel.or.id/category/opini/ , diunduh pada 10 Desember 2013 
sebagai mind actor, maka saksi dari masyarakat menyebutkan bahwa tidak ada perintah untuk maju apalagi merobohkan pagar Mapolda dari Dedek Chaniago maupun Anwar Sadat.

Perbedaan pendapat mengenai penyebab robohnya pagar Mapolda yang sangat signifikan, membuat penulis sulit untuk melakukan analisis apakah Anwar Sadat dan Dedek Chaniago telah melakukan partisipasi secara layak atau tidak. Namun dari kronologis fakta yang terungkap di persidangan, dapat ditemukan beberapa poin penting yaitu:

1. Anwar Sadat dan Dedek Chaniago merupakan aktivis Walhi yang kegiatannya meliputi: ${ }^{30}$ penyelamatan ekosistem, pengorganisasian rakyat, pendidikan kritis, kampanye dan riset, litigasi, menggalang aliansi kekuatan masyarakat sipil, dan menggalang dukungan publik, sebagaimana disebutkan dalam Anggaran Dasar Walhi.

2. Anwar Sadat dan Dedek Chaniago secara nyata melakukan aktivitas pendampingan bagi masyarakat Kabupaten OKI dalam konflik sengketa agraria dengan PTPN VII Unit Cinta Manis.

3. Pendampingan yang dilakukan Walhi tidak hanya dikarenakan konflik sengketa agraria namun juga karena aktifitas perkebunan PTPN VII yang terindikasi berkontribusi terhadap pencemaran wilayah sekitar. ${ }^{31}$

4. Aksi unjuk rasa yang dilakukan di depan Mapolda merupakan inisiatif masyarakat. ${ }^{32}$

5. Terjadi pemukulan terhadap Anwar Sadat dan Dedek Chaniago yang dilakukan oleh aparat kepolisian yang mengakibatkan tubuh Anwar Sadat terluka dibeberapa bagian.

Dari beberapa poin di atas, dapat dipastikan bahwa Anwar Sadat dan Dedek Chaniago merupakan aktivis yang memperjuangkan hak atas lingkungan hidup yang baik dan sehat. Hal ini terlihat dari posisi Anwar Sadat dan Dedek

\footnotetext{
30 Sebagaimana disampaikan dalam Nota Pembelaan "Bebaskan Tahanan Politik Agraria dari Peradilan Sesat atas Tuntutan No. Reg. Perk.: PDM - 390/ Ep.1/ V /2011 atas Nama Terdakwa

Anwar Sadat, St Als Sadat Bin Satim dan Dedek Chaniago Bin Edi yang Dituntut Pasal 170 Ayat (2) ke-1 KUH Pidana", hal.129-130

${ }^{31}$ Ibid., hal. 3

32 Ibid., hal. 74
} 
Chaniago secara struktural dalam kepengurusan Walhi Sumsel dan melaksanakan kegiatannya sesuai dengan Anggaran Dasar Walhi. Tindakan pemukulan yang dilakukan oleh aparat kepolisian merupakan tindakan intimidatif karena menimbulkan ancaman dan ketakutan bagi para pengunjuk rasa. Selain itu, penahanan yang dilakukan oleh aparat kepolisian yang dilanjutkan dengan dakwaan dan tuntutan di persidangan memenuhi salah satu unsur SLAPP yaitu adanya penuntutan perkara/gugatan . Dalam hal ini, tindakan yang dilakukan oleh aparat kepolisian memungkinkan digolongkan sebagai SLAPP, walaupun akan menimbulkan perdebatan mengenai kelayakan partisipasi terkait dengan robohnya pagar Mapolda.

Ada poin-poin yang masih menimbulkan ketidakpastian akan terjadinya SLAPP dalam kasus ini adalah:

1. Belum jelasnya maksud dari kalimat "satu aksi, satu komando, yang tidak satu komando adalah pengkhianat, dan pengkhianat halal darahnya diminum, 3 langkah ke belakang jalan" 33 merupakan kalimat provokatif atau tidak;

2. Tidak jelas diketahui siapa yang melontarkan kalimat "Hidup Petani, Hidup Petani, Hidup Petani, ... Maju-maju terus hancurkan terus" 34 sebagaimana yang didakwa oleh Jaksa Penuntut Umum;

3. Belum jelasnya apakah ada instruksi untuk merobohkan pagar Mapolda atau tidak;

4. Belum jelasnya siapa yang melakukan aksi merobohkan pagar Mapolda.

Keempat poin tersebut di atas penting untuk menentukan apakah partisipasi yang dilakukan oleh Anwar Sadat dan Dedek Chaniago telah tepat atau tidak, sehingga dapat dilindungi dengan ketentuan Pasal 66. Dikarenakan masih adanya ketidakpastian dan pada saat tulisan ini dibuat perkara ini masih dalam tahap kasasi, maka kasus Anwar Sadat dan Dedek Chaniago memungkinkan untuk digolongkan sebagai SLAPP.

\section{E. Kesimpulan}

Dari berbagai penjelasan di atas, didapat kesimpulan bahwa dalam kasus yang terindikasi SLAPP, sebaiknya tidak hanya memperhatikan tindakan offense atau

33 Ibid.

34 Putusan Nomor: 76/PID/2013/PT.PLG 
serangan balasan dari pelapor atau penggugat, namun juga harus diperhatikan apakah aktivitas partisipasi yang dilakukan telah layak atau tidak. Tidak mudah untuk menilai apakah suatu partisipasi telah layak atau tidak, tetapi setidaknya hal tersebut dapat dilihat dari norma-norma yang berlaku umum di masyarakat. Kasus yang dialami oleh Anwar Sadat dan Dedek Chaniago merupakan sebuah tindakan kriminalisasi, namun perlu kajian yang lebih mendalam untuk memastikan telah terjadi SLAPP. Oleh karena itu, sampai dengan artikel ini ditulis, penulis berkesimpulan kasus yang dialami oleh Anwar Sadat dan Dedek Chaniago memungkinkan untuk digolongkan sebagai SLAPP. 